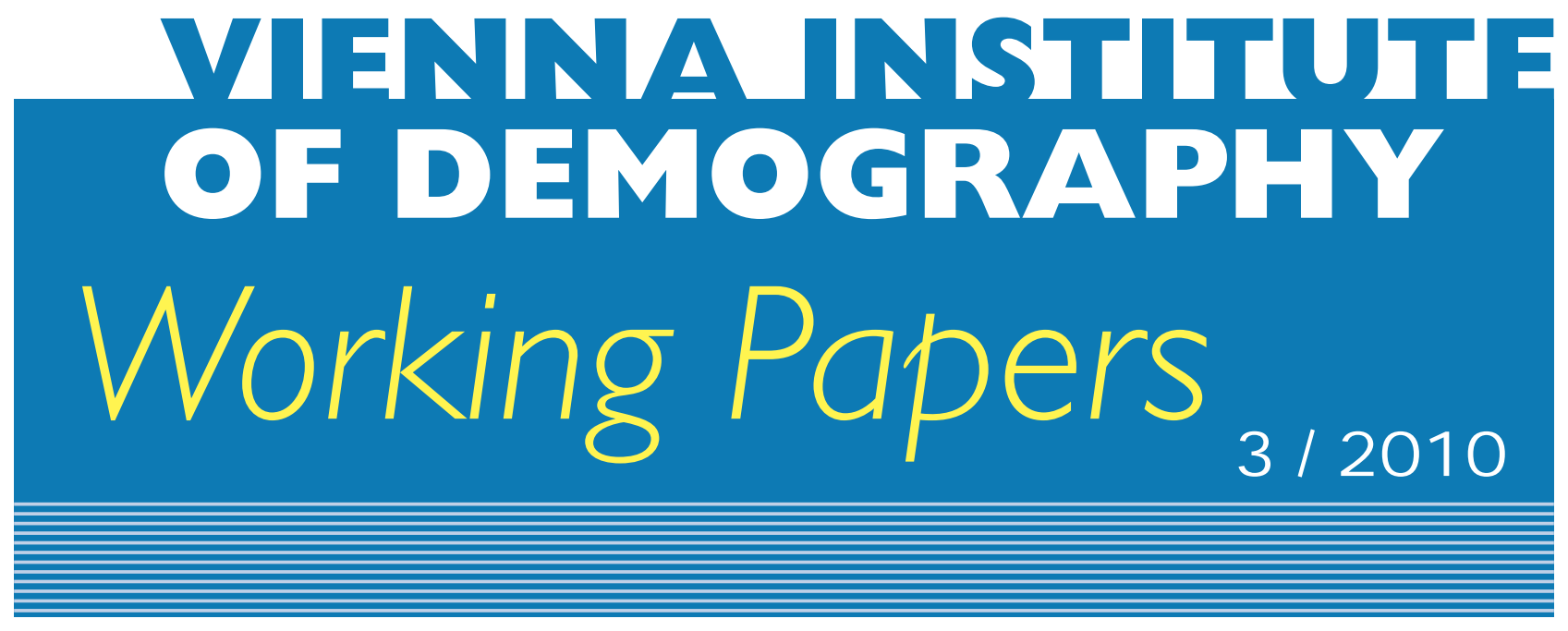

M aria Rita Testa

\title{
She Wants, He Wants: C ouple's Childbearing Desires in Austria
}

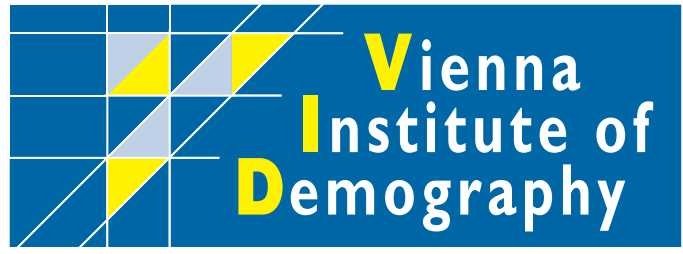

Vienna Institute of Demography Austrian Academy of Sciences

Wohllebengasse 12-14

A-I040Vienna $\cdot$ Austria

E-Mail:vid@oeaw.ac.at

Website: www.oeaw.ac.at/vid 


\begin{abstract}
This paper analyses couples' childbearing desires by using data from the Austrian Generation and Gender Survey (GGS) conducted in 2008. Couple disagreement is examined, first, independently of whether only she or he wants a child, second, by looking at the predictors of his and her dissent separately. Special emphasis is given to the role of the intra-household bargaining power of each member of the couple. Results show that disagreement is most likely for all unmarried couples that do not have any common child and if the male partner is unemployed. Moreover, conflict increases in all partnerships with at least one common child if the female partner has brought biological children from a previous relationship into the current union. Generally speaking, women attribute more importance to their own desires than to their partner's ones, while men give as much emphasis to their partner's fertility desires as to their own ones when they report their personal child-timing intentions. Couple disagreement is one of the most relevant predictors of subsequent fertility behaviour.
\end{abstract}

\title{
Keywords
}

Partner's fertility desire, fertility decision-making, couple agreement on childbearing plans, bargaining power, contraceptive behaviour

\section{Author}

Maria Rita Testa, Vienna Institute of Demography, e-mail: maria.rita.testa@oeaw.ac.at

\section{Acknowledgments}

I am grateful to Caroline Berghammer and Isabella Buber for their valuable help in getting acquainted with the Austrian GGS data, and to Dimiter Philipov and Leonardo Grilli for their beneficial comments on a first draft of the paper. 


\title{
She Wants, He Wants: Couple's Childbearing Desires in Austria
}

\author{
Maria Rita Testa
}

\section{Introduction}

This contribution studies couple disagreement about current childbearing desires in Austria.

Both the formation and the predictive power of birth intentions strongly depend on the two members of the couple (Fried and Udry 1979; Fried et al. 1980; Beckman 1984; Morgan 1985; Jansen and Liefbroer 2006) and on the level of their agreement (Miller and Pasta 1996; Rosina and Testa 2009).

The relevance of reproductive intentions and behaviour of couples has been recognised for a long time in the literature about fertility (Ryder 1973), but only few studies have provided in depth analyses of childbearing plans and reproductive behaviour by considering both partners (Fried and Udry 1979; Fried et al. 1980; Beckman et al. 1983; Morgan 1985; Toulemon 1987; Thomson et al. 1990; Thomson 1997; Thomson and Hoem 1998). In addition fertility research has continued to be primarily based on the female perspective. This has to do with the lack of adequate data, as data collection was often collected only from female respondents, or from men and women separately who were sometimes asked to report their intentions as a couple (Morgan 1985) but only very seldom from both members of a couple (Fried and Udry 1979; Fried et al. 1980; Beckman 1984; Toulemon 1987; Thomson et al. 1990; Miller and Pasta 1996; Thomson 1997; Thomson and Hoem 1998; Berrington 2004). As a consequence, there is no single theoretical framework for the specifics of a couple's fertility decision making process although some efforts have been done in this direction (Miller et al. 2004).

Fertility studies, adopting solely a female perspective, i.e. choosing to look at the characteristics of only one partner, have often been justified by the high degree of homogamy observed within couples, especially regarding education and religiosity. As a consequence, the social characteristics of the partners largely overlap, and make it redundant to focus on both partners' characteristics (Corijn et al. 1996). However, empirical research suggests that homogamy within couples is never quite complete and therefore looking at the characteristics of either the male or the female partner might yield potentially misleading results (Corijn et al. 1996).

Aside from the absence of a couple-oriented approach which is common to most of the European countries, the analysis of fertility intentions in Austria is characterised by a scarcity of micro-level studies. Aggregate analyses have pointed out that the young Austrian generations have the lowest low-fertility ideals and intentions in Europe, with values at around 
1.8 and 1.6 children, respectively (Goldstein et al. 2003; Testa 2006; Sobotka 2009). However, the individual determinants of stated fertility intentions have not been deeply investigated yet. An extensive work on birth intentions and their realisation in Austria was developed in the framework of a longitudinal study conducted by the Institute of Demography of the Austrian Academy of Sciences between 1978 and 1981/82. This analysis examined the predictors of intentions in a static and dynamic way but did not take into account partners' fertility intentions due to the lack of adequate quantitative information on the husbands of the 2700 interviewed married women (Gisser et al. 1985; Institut für Demographie 1980). More recently, a few articles have treated specific aspects of fertility preferences, like the influence of gender roles (Buber 2003; Tazi-Preve et al. 2004) and the effects of structural and financial incentives and constraints (Engelhardt 2004).

I aim to contribute to this field of research by looking at couples' present childbearing desires. Three main research issues are addressed in the current paper: (1) The determinants of couple disagreement concerning current fertility desires and, more specifically, whether there are gender-related reasons for his or her dissent (2) the degree to which the partner's child desire is implemented in the individual child-timing intentions (3) the influence of the partner's desire of having a child on the couple's joint proceptive behaviour. Desires are outlined as the immediate antecedent to intentions in the theoretical framework (Perugini and Bagozzi 2001) which proposes a modification of the Theory of Planned Behaviour (Ajzen 1991). Proception, as an instrumental behaviour aimed at achieving conception, has proved to be a relevant mediator factor between childbearing intentions and the occurrence of conception (Miller 1986).

A recent paper on couple disagreement about first birth intentions in Italy (Rosina and Testa 2009) has shown that conflict is more likely to arise among partners who presumably have more egalitarian gender roles, i.e. they cohabit and the female partner works in the labour market. In the current article I try to figure out whether such a result can be extended to the Austrian case. Austria is characterised by quite low gender equity (Buber 2002 and 2003) but female labour force participation rates are higher and the institutional settings for families with children are more generous compared to Italy. However, the two countries share a high level of incompatibility between childrearing and employment. The Austrian social policy mainly provides financial incentives to increase fertility, and although the financial situation of young parents has been improved, it has not really succeeded in making employment and family more compatible for women (Prskawetz et al. 2008).

The article is organised as follows. In Section 2 I review the main literature on couples' childbearing intentions. Section 3 is devoted to the presentation of the data and the methodology. Results of the descriptive and multivariate analyses are described in Section 4. Section 5 contains a discussion of the main implications of partners' fertility intentions as reported by the respondents, while Section 6 summarises and discusses the main findings. 


\section{Background}

The fertility decision-making process is an extremely complex process due to the heterogeneous nature of the reproductive behaviour, which encompasses biological, psychological, dyadic and social dimensions. The dynamic resulting from a couple's interaction represents a relevant component of it (Beckman 1983).

The literature review has shown that men and women both make independent contributions to fertility decisions (Beckman et al. 1983; Beckman 1984; Miller and Pasta 1995; Thomson et al. 1990, Thomson 1997; Thomson and Hoem 1998) and that people perceive fertility choices as joint couple decisions which justifies the analysis of jointly decided couple intentions (Morgan 1985). Moreover, both partners influence the decision about childbearing irrespectively of whether the partnership is a traditional or an egalitarian one (Thomson 1997; Thomson and Hoem 1998).

In economic literature a couple's perspective was adopted after women had started to achieve higher levels of education as well as higher income and had also gained stronger authority in the decision-making process within the household. As a consequence, the unitary models developed in the 1960s were replaced by non-unitary models in the early 1980s. The former ones treat the family as a single decision-making agent with single pooled budget constraints and a single utility function that includes the consumption and leisure time of every family member. In contrast, the latter ones rely on cooperative game theory, which assumes that players can make binding commitments and give emphasis to individual bargaining power (Lundberg and Pollak 2007).

The studies that focused on conflicting fertility intentions between partners have brought evidence that the resolution of a disagreement depends: 1) on the type of the decision each partner wants to make, 2) on the existing level of gender equity, both at individual and societal level, 3 ) on the prevalent rule adopted by the couple in disagreement.

Type of decision. Usually women prevail in positive fertility decisions whereas men predominate in negative childbearing plans. Townes et al. (1980), for example, argued that specifically the opinion of the wife is more important than the husband's in determining whether couples will seek pregnancy, if the wife is in favour of a pregnancy. Similarly, Beckman (1983) pointed out that in case of disagreement the male view prevails in anti-natal decisions, while a female opinion is dominant in pro-fertility decisions. However, in a study on a sample of well-educated couples, Beckman (1984) found out that with regard to couples with discordant opinions wives are less likely to desire another child in the short-run than husbands.

Gender equity. In their article 'Psychology of Child-Timing' (1994), Miller and Pasta stated that although both partners influence the formation of intentions, females consider their own intentions as more relevant, while males treat their and their partner's child-timing intentions 
as equal. They explained these results with the fact that women play a more central role in childrearing activities in the US, where the study was conducted. For the same reasons marital dissatisfaction or conflict only affects men's child-timing intentions, i.e. the intention to delay childbearing, but not women's (Miller and Pasta 1994). In the same line, Fried et al. (1980) and Beckman (1984) argued that the wife's characteristics can be more closely related to intentions than the husband's characteristics because contraceptive use and fertility are considered as areas in which women have legitimate power in the marriage. In the same line, Rindfuss et al. (1988) showed that men adjust their intentions more easily to the preferences of their partner than vice versa.

Decision rule. Miller and Pasta (1996) disentangled two main components that evocate disagreement: the signed difference effect, and the absolute difference effect. The first one depends on the partner who has more influence on the reproduction behaviour. The second one is independent of the predominant partner because it is linked to the so-called inertia mechanism. Inertia is in favour of maintaining the status quo. Consequently if contraception between births is the prevalent regime, the partner who does not want a child prevails or alternatively, the partner who wants a child, if the prevalent regime is the non-use of contraception. The mechanism which creates inertia has been deeply studied by Davidson and Beach (1981) and Beach et al. (1982). Voas (2003) suggests that in modern societies individual autonomy is more relevant than childbearing and therefore social forces would support the partner who wishes to avoid a birth. For this reason and because of an inertia mechanism, consent is expected before any attempt to conceive and childbearing only takes place when an agreement on reproduction plans has been reached (Voas 2003). Following the study of Miller and Pasta, Jansen and Liefbroer (2006) discussed four different decision rules that could be adopted by partners in disagreement in order to arrive at a joint fertility decision: (1) The power rule, according to which influence is determined by access to social and economic resources, i.e. the more powerful partner will prevail the decision making process; (2) the golden mean rule, that means that partners have an equal say in negotiations; (3) the sphere of interest rule, that applies when women show greater influence in childbearing issues according to the traditional gender ideology; ${ }^{1}$ and (4) the social drift rule, that indicates that disagreement leads to maintaining the status quo.

The authors found out that both partners play an equally important role in the decision making concerning first childbirth and other issues that require joint decisions in the Netherlands. This means that the golden mean decision rule is operative in the majority of cases with diverging views. However, whenever both partners are not very interested in changing the status quo, they may opt to make use of the social drift rule in order to resolve their conflict. These findings that recall those of previous studies (Thomson 1997; Thomson and Hoem 1998) emphasise that in contemporary households partners have equal influence on joint decisions and that bargaining has become an important decision making factor for spouses with different interests.

\footnotetext{
${ }^{1}$ This rule implies that as men increase their household and child care responsibilities, they will acquire greater influence in childbearing decisions.
} 
In light of these results, although they cannot be extended tout court to the Austrian case, I decided to consider the role of the intra-household bargaining power with regard to the current analysis of couple disagreement.

\section{Data and Methods}

The data used in the current analysis was taken from the survey "Familienentwicklung in Österreich", conducted by the Austrian National Statistical Office in 2008 in the framework of the international "Generations and Gender Programme". The sample includes 5000 individuals, men and women, aged 15-44 years. As the analysis focuses on couples' fertility desires, I consider only those individuals who were living in a union at the time of the interview, irrespectively of whether they were married, cohabiting, or living apart together.

The analytical sample includes 3402 heterosexual couples of which the interviewed person was aged 18-45 years, and the female partner was neither pregnant nor older than 50 at the time of the interview. I further restricted the sample to couples of which neither of the partner had been surgically sterilised and the respondent, either she or he, answered both questions about their partner's childbearing desires. Non-response rate was very low (5\%).

\subsection{Dependent Variables}

The key dependent variable reflects the respondent's as well as the partner's childbearing desires which are combined to analyse couple agreement or disagreement. In the survey individuals were asked to report not only their own fertility desire (Do you yourself want to have a/another child now?) but also their partner's fertility desire (Does your partner want to have a/another child now?), if they had a partner. This last question was introduced by the following statement: "Couples do not always agree on when and how many children they want'. Response options to the respondent's fertility desire were: yes, no, or don't know, and in the partner's desire question: yes, no, partner not sure, or don't know. Two important remarks should be made on the wording of the selected questions: The verb 'want' rather than the more committed 'intend' was chosen as well as the generic expression 'now' instead of a more specific time framework. Both features may make the responses to the selected items quite general as they reflect only wishful thinking rather than realisable plans. Indeed, the literature on fertility decision making processes generally uses the term want to capture desires that reflect wishes and do not lead directly to action because they have to be translated into intentions (conscious commitments to act), before they are transformed into behaviour (Miller and Pasta 1996). According to this view, desires differ from intentions because they are based on feelings and do not incorporate any situational constraint. The Austrian GGS also incorporated a question related to fertility intentions ("Do you intend to have a/another child during the next three years?") but it was addressed only to the respondents and not to the 
partners and it encompasses a larger temporal frame as compared to the item that is only interested in desires (three years rather than now).

Since the way in which the two questions on fertility desires and intentions are worded is not without ambiguity and the interviewers were not trained to preliminary explain the distinction between desires and intentions to the respondents, it is well possible that the interviewees understood these items in different ways. For this reason I run an exploratory analysis with regard to the question about fertility desires with the main aim of figuring out which of the interpretations prevailed.

First, I found that in this scenario the group of respondents who desire a/another child now largely overlaps the group of those who intend a/another child within the next three years: $84 \%$ of those who said that they want a baby now, also declared that they intend to have a child during the next three years. Remarkably, the awareness of the partner's dissent is an important factor for expressing only a desire instead of an intention: Among those who expressed that they want a child now but stated that they are not intending to have a child within the next three years, almost $70 \%$ report discordant desires.

Second, I discovered that those who only want a child now but show no intentions of having one within the next three years are less likely to use contraception than those intending a child during the next three years but not wanting one now (59\% against $85 \%)$. This empirical evidence runs in favour of the expression 'now' as being understood as 'as soon as possible' or 'at the very moment'.

Summing up, beyond the confused terminology used in the survey questions, couple childbearing items used in this analysis may be considered as reflecting concrete but temporary childbearing plans referred to at the time of the interview.

Couple disagreement is defined as any discrepancy between the respondent's and the partner's desire of having a child, independently from the level of the disagreement. This means that cases when the respondent says 'yes' and reports for their partner a 'no' answer, are equally treated as cases when the respondent indicates 'yes' and reports that their partner is not sure about having a(nother) child or not: both are considered as conflicting desires.

Like Miller and Pasta (Miller and Pasta 1996), I distinguish between positive and negative disagreement: the former refers to dissent on not having a child while the second refers to dissent on having a child. The distinction is necessary because the predictors of couple discordance are presumably very different in the two cases.

The dependent variable of the models analysing the individual child-timing intentions is based on the survey question phrased as follows: "Do you intend to have a/another child during the next three years?” Response options were: 'Certainly not', 'Probably not', 'Probably yes' and 'Certainly yes'. 
The dependent variable of the models analysing the couple proceptive behaviour is computed on the basis of the survey question phrased as follows: "Do you currently use contraception?"

\subsection{Methods}

The multivariate analysis is developed by running logistic regression models. Three main models are employed to detect the significant predictors of couples' discordant desires. The first one is run on the whole sample of couples and uses a response variable equal to 1 if the partners disagree on having a(n additional) child, independently of whether she or he desires a child, and 0 otherwise. The second model selects only couples of which the female partner desires to have a(n additional) child. This model uses a response variable equal to 1 if men do not want to have a child, either in general or an additional one, and 0 otherwise. The third model selects only couples of which the male partner desires a(n additional) child and uses a response variable equal to 1 if the female partner does not want to have a child, either in general or an additional one, and 0 otherwise. According to this setting disagreement is general for model I and negative (related to the partner's positive fertility intentions) for models II and III. This methodological choice has been made to disentangle the four components inherent in our response, the fertility desires, positive or negative, and the disagreement, positive or negative, while keeping the couples as units of analysis and giving special emphasis to the dissent of either partner on having a child. The main disadvantage lies in the fact that models II and III have quite a low sample size. Moreover, by considering only those couples of which at least one of the partners wants to have a child, selection is introduced with the consequence that the estimated coefficients may be biased and inconsistent if unobserved factors affecting couple disagreement and fertility desires are correlated. I check for possible selection biases by using Heckman selection probit models (Heckman 1978 and 1979).

In the logistic regression models used to detect the predictors of individual child-timing intentions the response variable is equal to 1 if the respondent reports to be very sure of intending a child during the next three years, and 0 otherwise. Since information on intentions is only available from one of the partners I could not adopt a genuine couple approach by distinguishing between the male and the female partner, but had to run the regression models first on the whole sample and then separately on male and female respondents.

In the logistic regression models used to detect the predictors of the proceptive behaviour of couples, the response variable is equal to 1 if the respondent reports a nonuse of contraception, and 0 otherwise. These models are run separately on male and female respondents, as the report on contraceptive use is available only from the interviewee which prevents me from adopting a pure couple approach.

All models are stratified by parity. Parity is defined as the number of children born in the current union, in order to include a useful covariate on stepchildren. Accordingly, separate models are run on childless and parent respondents. This methodological choice has been 
made because the predictors of childbearing intentions could be very different in the two selected groups, in line with a conditional-sequential fertility decision making process (Namboodiri 1972; Bulatao 1981). As pointed out in the demographic literature (Kravdal 2001), a problem arises from the parity specific analysis. It is the selection, the presence of unobservable variables that could be correlated with the probability of having a child in the parity $n$ as well as with the probability of intending a child of the next order, $n+1$. The consequence is a biased and inconsistent estimator. This problem is not tackled here for the lack of adequate longitudinal information but the related issue is discussed in the concluding section.

\subsection{Independent Variables}

The explanatory variables used in the models are the following: type of union, duration of partnership, individual education, individual employment status, woman's age, individual stepchildren (i.e. children from a previous union), number of common children, years elapsed from the birth of the last child, geographical area of residence, educational difference between the partners, male involvement in household tasks and child care duties. The distribution of the variables used in the multivariate analysis is given in Table 1.

The difference in education has been included in order to capture the influence of the degree of intra-household bargaining power on the relative weight given to each partner's fertility intentions (Lundberg and Pollak 1996). The variable is codified in three categories: men higher educated than women, same level of education of men and women, women higher educated than men. Either one of the two partners is considered as higher educated if the achieved education level is higher than the partner's, independent of the extent of the gap between the two education levels. A refinement of the variable that takes this gap into account has not been introduced because the sample sizes are too small.

Male involvement in household tasks is measured with a dummy variable equal to 1 if men take part in at least four different traditional feminine household tasks: cooking, washing the dishes, grocery shopping and vacuuming, and 0 otherwise. Previous studies have shown that partners often differ in their report on the division of household and child care tasks (Kamo 2000). This circumstance seems to be supported by the Austrian GGS data that states that only $7 \%$ of the interviewed women but $16 \%$ of the interviewed men report a man's participation in all the above mentioned household tasks. Since the data at hand provides information from just one of the partners, I am not able to rigorously test for the possibility of partners' discrepant reports. In order to see whether the gender of the reporting partner influences the estimated impact of men's participation in household and child care tasks with regard to couple disagreement I consider an interaction between the sex of the respondent and the variables related to male participation in household and child care tasks respectively. I do not include these interactions in the final models since none of them was found to be statistical significant. 
The involvement of the male partner in child care is measured with a dummy variable equal to 1 if men take part in at least six of the following child care duties: dressing the children, bringing them to bed, staying with them at home when they are sick, playing with or spending their leisure time with them, helping them with their homework, taking them to school or to kindergarten, and 0 otherwise. Interaction variables between this covariate and gender are not included in the final models since none of the estimated interaction effects was found to be statistical significant.

All the results given in the paper are weighted with a special weighting system elaborated by the Austrian Statistical National Office and the Vienna Institute of Demography. These weights adjust for age, sex, employment ${ }^{2}$, country of birth, living arrangement and age specific parity distribution. For further details see Buber-Ennser (2009).

\section{Results}

\subsection{Descriptive Analysis}

Overall, couple disagreement concerning current fertility desires is quite rare; around $10 \%$ of partners disagree, evenly divided between men wanting a child when women do not and vice versa (Table 2). The vast majority of agreement concerns the wishes not to have a child (Table 2). In reading this result we should keep in mind that these preferences represent a short-term perspective and do not imply any long-term decision.

The shared responsibility of contraception among couples with conflicting fertility desires is quite high (between $62 \%$ and $80 \%$ if the respondent is female and between 71 and $78 \%$ if the respondent is male) and definitely closer to that shown by partners who both agree not to have a child (84-80\%) as to that when both partners agree to have a child (27-33\%) (Table 2). Consistently with previous studies (Miller and Pasta 1996), the behaviour of couples with disagreeing childbearing desires is more similar to that of couples in which both partners want no (more) children than to that of couples with a shared desire for (more) children.

A couple's agreement is strongly related to the certainty component of child-timing intentions: the proportion of those very confident about their birth intentions goes from 67 and $68 \%$ respectively among female and male respondents of couples of which both intend a child to 6 and $4 \%$ respectively among female and male respondents of couples of which both do not intend a child. Women give more importance to their own point of view as compared to men: If only they intend to have a child, they are more confident about their birth intentions (35\%) as if only men intend a child $(13 \%)$. In contrast, men attribute almost the same level of certainty to their fertility intentions as to their female partner's fertility intentions: $22 \%$ are very sure about their intent of having a child within the next three years if only this is as well

\footnotetext{
${ }^{2}$ For the German version of the survey questions used in the current analysis see Table A1 in the Appendix.
} 
the female partner's wish while $26 \%$ are very sure about their child-timing intentions if only he wants to have a child (Table 2).

By selecting only couples of which only one of the partners wants a child I focus on negative disagreement, i.e. dissent on having a child. On the whole 28 and $29 \%$ of men are in disagreement with the female partner's intentions to have a first or additional child respectively, while $31 \%$ and $42 \%$ of women are in disagreement with their male partner's intentions to have a first or an additional child respectively (Table 1). In Figure 1 I show the distribution of partner's current fertility desires by parity separately for female and male, by selecting respectively those couples where either he or she wants to have a child now. Evidently, women's and men's dissent on having a child is increasing by parity after the transition to the first child (Figure 1). Moreover, a couple's conflict about current fertility desires increases with the age of the female partner (Figure 2).

\subsection{Multivariate Analysis}

The multivariate analysis lends additional support to the choice of stratifying the models by parity: The predictors of couple's disagreement in childbearing intentions are quite different for the two groups of childless partnerships and those who already are parents.

\subsubsection{Determinants of Couple's Disagreement about Current Fertility Desires}

Childless couples. Couple disagreement on first child desires is positively associated with the cohabiting status: Childless partners in cohabiting unions are more likely to have conflicting childbearing intentions than couples who are married. This evidence seems to support the circumstance that cohabitation, although very widespread in Austria (Prskawetz et al. 2008) is not yet equal to being married when it comes to start a family. ${ }^{3}$ One explanation could be that married couples are in a more advanced stage of a family formation process and hence they are more ready to start parenthood than cohabiting couples. But, it could also be that people who choose to cohabit tend to have less traditional family values and attitudes (Kiernan 2004) than married couples and consequently they are more likely to express their own opinion even when it may be in conflict with their partner's position.

The male breadwinner model seems to predominate: If the male partner is not employed, the chance of couple disagreement on first birth intentions increases, while if the female partner is not employed declines. The concordant opinion of non-working women with their partners' first child intention may be interpreted in two different ways: They can take benefit of their current unemployment status to think about and concretely plan motherhood, or they actually

\footnotetext{
${ }^{3}$ The positive association between cohabitating status and disagreement does hold also when the cohabiting couples are sub-divided between those living in the same household and those living apart together. Both these variables take positive and statistically significant coefficients.
} 
have less power to contradict their partner's opinion. Consistently with the male breadwinner model, childless Austrian women are more likely to dissent to become a parent if the male partner is still studying.

The increasing level of couple disagreement on first childbearing concerning female age is not fully supported by the multivariate analysis. The estimated coefficients are always very small and not statistical significant, meaning that once several socio-demographic characteristics are considered the age effect becomes negligible.

The unequally distributed bargaining power is negatively associated with couple's disagreement: The more unequal the gender bargaining power, the more likely it is that the partners will be concordant in their childbearing plans (Table 3). Within an unequal setting it could be easier for the weaker partner to adapt her/himself to the decision of the stronger partner. The effect is statistically only significant in case of female negative disagreement (Models III) that appears to be less likely when men are more educated than women.

Regarding couple disagreement about the desire to become parents in the first place, no significant effects of stepchildren could be found. This is in line with previous research that has shown that stepchildren have no implications on first child rates in Austria (Buber and Prskawetz 2000). In contrast, the mentioned study made clear that the place of residence of stepchildren, more precisely, whether they live in the same household with their parent and the parent's new partner or not, was found to be a relevant factor that does influence the reproductive behaviour of people in a second union. I did not consider such a factor in the current analysis because there are too few stepchildren who are not part of the new household/union of their mother.

Couples with at least one common child. Disagreement about the desire to have an additional common child is positively associated with the current number of children shared by the couple and with the woman's previous biological children.

Beyond these effects the model detecting the reasons of his dissent on wanting a child (Model II), shows an additional significant effect of male and female education, men's prevailing bargaining power, and men's involvement in child care tasks.

The effects of different education levels go in opposite direction: a higher female education level increases the chance of male disagreement while a higher male education level decreases the likelihood of his dissent on having an additional baby.

Male prevailing bargaining power within the couple increases the likelihood of his dissent on having an additional child. The involvement of the male partner in child cares decreases the chance of his disagreement about the desire to have a child. The result is in line with previous research (Buber 2002) which showed that second births intentions in Austria are positively associated with an equal gender division of child care duties within the couple. 
The cohabitation effect almost disappears in the models run on parents (but it is still significant in Model II). This could be due to the low proportion of cohabiting couples among those who already have a child. Indeed, although a high share of cohabiting partners have a child out of wedlock in Austria, the vast majority of them marry soon after the first child is born (Heuveline and Timberlake 2004; Prskawetz et al. 2008).

Estimates coming from Models II and III in Tables 3 and 4 were found to be robust with regard to potential selection effects due to the fact that couples of which alternatively the female partner (Model II) or the male partner (Models) with a desire for a child were selected out of all couples in the available sample. Moreover, the effects of the covariate on men's stepchildren has also been found to be statistically significant in the models only run on those couples with just one common child (parity 1) by controlling for the potential selection effect due to the fact that unobserved factors linked to the probability to have a first child may also be linked to the probability of wanting a second child.

\subsubsection{Effects of Partner's Discordant Fertility Desires on Individual Child-Timing Intention}

The logistic models estimating the probability of being very sure to intend a child within the next three years show that the respondent's and the partner's perceived desire to have a child now are both relevant in the formulation of child-timing intentions (Table 4): A desire for a child, stated either by the partner or the respondent, increases the chance of expressing an intention for a child. However, while in models for males the coefficients for the respondent's and the partner's desires are almost the same (childless models) or close to each other (parents models); in models for females the respondent's desire coefficient is more than three times higher (childless models) or almost doubles (parents models) than compared to the partner's desire coefficient. This means that men take their partner's desire for a child more into account than vice versa. The individual intention of having a first common child with the current partner is also negatively correlated with the female age in both models for male and female respondents, with male unemployment status in the models for males, and with high female education and previous biological children in the models for females. The individual intention to have an additional child with the current partner is negatively associated with the current shared parity and the time duration from the birth of the last child in both models for male and female respondents. In addition, men are less likely to intend to have a child if they hold the prevailing bargaining power, and women are less likely to intend having a child if they are older or unemployed (Table 4).

\subsubsection{Effects of Partners' Discordant Fertility Desires on Individual Proceptive Behaviour}

Respondent's and their partner's current fertility desires are both significantly and positively correlated to the likelihood of reporting a non-use of contraception (Table 5). However, in the models for male respondents the related coefficients are very close to each other while in the models for female respondents the respondent's desire coefficient is twice as 
high as compared to the partner's desire coefficient. This implies that women are more likely to report a non-use of contraception if they want to have a child as if their partner wants to have a child. The female point of view seems to be predominant in the reproductive decisions.

Moreover, the non-use of contraception is positively associated with the duration of the union, the female age and unemployment status, and negatively associated with women's previous biological children in the models for female respondents who do not have a common child with the current partner. While it is negatively associated with the cohabiting status, male enrolment in school as well as a high male education level in the models for male respondents without common children with the current partner (Table 5). Interestingly, the covariate related to the intention to have a child during the next three years is significantly correlated with the proceptive behaviour only in the models for females. That means that unlike men, women do include some additional constraints in their child-timing intentions beyond the current partner's desire. This gender effect disappears in the models run on couples with at least one common child where the child intention variable is statistically significant only in the models run on men and women together. Among these couples who already share a child a negative effect of cohabitation and female age is detected in the models for male respondents and a positive effect of male and female unemployment is evidenced in the models for female respondents.

\section{The Consequences of Using Respondent's Proxy Reports of Partner's Fertility Desire}

The empirical findings shown in the current analysis are based on the respondent's proxy report of the partner's desire for a/an additional child. These proxy reports have been shown to be biased by the individual's own point of view (Williams and Thomson 1985; Morgan 1985).

In the Austrian GGS a subset of the interview questions was administered to the partners of respondents living in a union with the experimental aim to keep the partner busy during the interview of the respondent. Questions on fertility desire and intention are included in the partner's questionnaire but no questions on contraceptive use. From 3892 partners who were asked to participate, 1115 returned the questionnaire. ${ }^{4}$ The response rate was very low, $29 \%$, and although it is not correlated with the partner's agreement about current fertility desires, it narrows the possibilities to run any robust statistical analysis on couples' childbearing desires by looking exclusively at the sub-sample of those people with an interviewed partner.

However, since there are 921 individuals for whom reliable information on their partner's desire is available in both versions, as reported by the respondent and by the partner, I looked

\footnotetext{
${ }^{4}$ In the sub-sample of respondents with an interviewed partner couples who are married, with children and where the male partner is the main respondent tend to be over-represented.
} 
at this small sub-sample to assess the accuracy level of respondent's proxy report and the possible biases that could affect the results stemming from my analysis.

The overall share of consistency between respondent's proxy report and partner's actual report of their fertility desire is quite high: $88 \%$ among male respondents and $90 \%$ among female respondents (the level is a bit lower if we consider only childless couples: $82 \%$ and $88 \%$ respectively).

The respondent's proxy report overestimates the agreement and underestimates the disagreement between partners as compared to the partner's objective report (Figure 3). The overestimation of couple agreement is more pronounced if the respondent does not want to have a child. The underestimation of couple disagreement is particular high if the respondent does not want to have a child while the partner does. Moreover, the inconsistency between perceived and actual fertility desire of the partner is significantly higher in the case of couples with conflicting desires but it is statistically not significantly associated with any of the background explanatory variables used in the current study (with the only exception of cohabitation in the childless models). This means that the effects of the background covariates on couple disagreement stemming from the current analysis could be assumed to be genuine (i.e. not due to the confounding effect of a misreported partner's desire).

\section{Discussion and Concluding Remarks}

This paper focused on couple agreement and disagreement about current fertility desires by distinguishing couples with and without common children.

Couples are used as units of analysis with the main advantage to encompass the influential factors coming from the male and the female partner in a unitary framework. The approach is quite innovative, as most studies that consider couples both partners are treated separately, by including the partner's characteristics in model runs on women's samples and vice versa.

The main research questions were related to the determinants of a partner's negative disagreement about current fertility desires and to the influence of the partner's child desire in the individual report of child-timing intentions and current proceptive behaviour.

First, I found that cohabiting couples face a higher risk to be in disagreement about current first childbearing desires consistently with the interpretation of cohabitation being only a stage in the marriage process in Austria (Heuveline and Timberlake 2004). Second, I evidenced that beyond the current number of couples' common children, the woman's previous biological children increase her dissent on having an additional child if she shares already one child with the current partner. These findings are consistent with previous studies that have evidenced a negative effect of men's stepchildren on childbearing intentions and childbearing risks (Stewart 2002). 
Third, I added some support to the hypothesis stated in a previous study (Rosina and Testa 2009) that couples' disagreement about the desire of a first common child is more likely between partners with egalitarian gender roles, i.e. they are cohabiting, the female partner works in the labour market and the partners have equal bargaining power. A similar result could not be observed in partnerships that already share one or more children. In this case disagreement is positively correlated with variables indicating the presence of more traditional settings, for example, where he has more bargaining power, and negatively correlated with variables which denote high gender equity, like men's involvement in child care tasks. The consideration of the type of fertility decision that has to be taken, whether pro or anti fertility, may help to read this contradiction. Since females tend to prevail in pro fertility decisions and males in anti fertility decisions (Townes et al. 1980; Beckman 1983) I could argue that the prevailing male bargaining power could increase - in given circumstances - the chance of his dissent on the partner's desire to have an additional child, while the prevailing female bargaining power could-in given circumstances-decrease the likelihood of her disagreement about the partner's desire to have an additional child. Fourth, I suggest that both women and men take into account their partner's current fertility desire when they report their individual child-timing intentions and the use of contraception, but men give as much importance to their partner's desires as to their own desires while women attribute more relevance to their own child desire.

Eventually, the perceived partners' desire to have a child is an important predictor of the individual reported proceptive behaviour, as shown in previous studies (Miller 1986).

The study has several shortcomings.

One caveat concerns the selection problem affecting the models run on couples who already have at least one common child. As it is well known, this selection may produce biased estimates if unobserved factors correlate with the likelihood to have a child of order $n$ are also correlated with the probability of intending a child in the next order, $n+1$. Although I am aware of such potential biases, I could not offer a valid model to deal with this problem in the current paper due to the lack of adequate data containing rich retrospective information. Since both the intended and the actual parity are changing over time and since they influence each other dynamically, a deep understanding of the process of their inter-dependency would require a longitudinal study that would allow me to build a complex dynamic model of simultaneous equations. Relevant progress in this respect could be made if a second survey would be carried out. In this context an additional research challenge could be faced: It would be interesting to consider the double selection process due to the fact that people are observed at a different actual and desired parity of their reproductive career in one single model.

A second major caveat concerns the ambiguous terminology of fertility preferences adopted in the Austrian GGS questionnaire. Fertility desires are used with a closer time referent as compared to fertility intentions while in the theoretical literature they are assumed to be a worst predictor of fertility behaviour (Miller and Pasta 1996; Armitage and Conner 2001). Although I am aware that respondents may get confused by the wording of the two questions, 
I showed that the vast majority of the interviewees interpreted the question in a reasonable way: Desires tend to overlap intentions unless obstacles, like a partner's discordant desire, are envisaged. Moreover, the current analysis showed that fertility desires could be the most suitable context to investigate couples' interaction because fertility intentions may incorporate, as some literature (Miller and Pasta 1996) and my empirical findings evidence, the perception of the partner's desire. They might thus conceal partners' conflict by already reflecting the resolution of couples' interactions. Indeed, in some studies using variables close to the fertility intentions a remarkably high degree of homogeneity in partners' responses has been found (Berrington 2004). The use of the adverb 'now' helps to capture the partners' conflict which may vary over time given that desires are frequently reassessed over the individual life course (Morgan 1985).

A third caveat refers to the use of respondent's report of partner's fertility desires. Ideally, research on couple's fertility decision making process should be based on surveys where both partners are independently interviewed (Thomson 1997; Thomson and Hoem 1998). However, the current analysis showed that having a double source of information on partner's desires, as perceived by the respondent and self reported by the partner, may ease the interpretation of conflicting desires and improve the knowledge on how the partner's dissent is implemented in the individual childbearing intentions.

The quantitative research on couple childbearing intentions in the European context relies only on a few papers (Thomson and Hoem 1998; Berrington 2004; Rosina and Testa 2009). In the attempt to fill into this scanty literature, the current paper tried to make a step forward in the analysis of couples' childbearing decision making process. As mainly people living in a partnership experience pregnancy and birth, the couple is the most suitable context of investigating fertility-decision making patterns.

This analysis sheds some light on the reasons why people do not always succeed to realise their previously stated childbearing plans. In the theory of fertility decisions (Miller and Pasta 1995; Toulemon and Testa 2006) partners' intentions are one of the main variables explaining the inconsistency between intended and actual reproductive behaviour. Empirical findings have shown that the lack of a suitable partner, or problems in the partnership, are the most frequently reported reasons for not having reached the initially intended parity at the beginning of the reproductive career (Testa 2006). Moreover, changes in the partnership status are among the most important reasons to revise previously reported fertility intentions ( $\mathrm{Qu}$ et al. 2000; Mitchell and Gray 2007).

In my study more than one out of three respondents who plan to have a child encounters the opposition of the partner, by ignoring the partner's disagreement we would neglect that this selected group will most probably not actively try to conceive till an agreement has been reached within the couple. 


\section{References}

Ajzen, I. 1991. The Theory of Planned Behavior. Organizational Behavior and Human Decision Processes, 50: 179-211.

Armitage, C.J. and M. Conner. 2001. Efficacy of the Theory of Planned Behaviour: A meta-analytic review. British Journal of Social Psychology 40(4): 471-499.

Beach, L.R., Hope, B.D. and F.L. Campbell. 1982. The expectation-threshold model of reproductive decision making. Population and Environment 5: 95-108.

Beckman, L.J. 1983. Communication, power, and the influence of social network in couple decisions on fertility, in: Bulatao, R.A. and R.D. Lee (Eds.) Determinants of fertility in developing countries, Vol.2, New York: Academic Press: 415-443.

Beckman, L., Aizenberg R., Forsythe A.B. and T. Day 1983. A theoretical analysis of antecedents of young couples' fertility decisions and outcomes. Demography 20(4): 519-533.

Beckman, L.J. 1984. Husbands' and wives' relative influence on fertility decisions and outcomes. Population and Environment: Behavioral and Social Issues, 7: 182-197.

Berrington, A. 2004. Perpetual postponers? Women's, men's and couples' fertility intentions and subsequent fertility behaviour. Southampton Statistical Science Research Institute, Applications Working Paper A04/09.

Buber-Ennser, I. 2009. Comparison of the Austrian GGS applying VID-weights with the Austrian Microcensus. Unpublished manuscript.

Buber, I. 2003. The influence of the distribution of household and childrearing tasks between men and women on childbearing intentions in Austria. Vienna Yearbook of Population Research 1: 165-180.

Buber, I. 2002. The influence of the distribution of household and childrearing tasks between men and women on childbearing intentions in Austria. MPIDR Working Paper 4.

Buber, I. and A. Prskawetz. 2000. Fertility in second unions in Austria: Findings from the Austrian FFS. Demographic Research 3(2).

Bulatao, R.A. 1981. Values and disvalues of children in successive childbearing decisions. Demography 18: 1-25.

Corijin, M., Liefbroer, A.C. and J. De Jong Gierveld. 1996. It takes two to tango, doesn't it? The influence of couple characteristics on the timing of the birth of the first child, Journal of Marriage and the Family, 58: 117-126.

Davidson, A.R. and L.R. Beach. 1981. Error patterns in the prediction of fertility behaviour. Journal of Applied Social Psychology 11: 475-488.

Engelhardt, H. 2004. Fertility intentions and preferences: Effects of structural and financial incentives and constraints in Austria. Vienna Institute of Demography Working Paper 2.

Fried, E.S., Hofferth, S.L. and J.R. Udry. 1980. Parity-specific and two-sex utility models of reproductive intentions. Demography 17(1): 1-11.

Fried, E.S. and J.R. Udry. 1979. Wives' and Husbands' expected costs and benefits of childbearing predictors of pregnancy. Social Biology 26: 256-274.

Gisser, R., Lutz, W. and R. Münz. 1985. Kinderwunsch und Kinderzahl. In: Münz R. (eds.). Leben mit Kindern: Wunsch und Wirklichkeit. Wien: Franz Deuticke: 33-93.

Goldstein J., Lutz, W. and M.R. Testa 2003. The emergence of sub-replacement fertility ideals in Europe. Population Research and Policy Review 22(5-6): 479-496.

Heckman, J.J. 1978. Dummy endogenous variables in a simultaneous equation system. Econometrica 46(4): 931-959.

Heckman, J.J. 1979. Sample selection bias as a specification error. Econometrica 47(1): 153-162. 
Heuveline, P. and J.M. Timberlake. 2004. The role of cohabitation in family formation: the United States in comparative perspective, Journal of Marriage and Family 66: 1214-1230.

Institut für Demographie 1980. Kinderwünsche junger Österreicherinnen. Institute of Demography of the Austrian Academy of Science.

Jansen, M. and A.C. Liefbroer. 2006. Couple's attitudes, childbirth, and the division of labor. Journal of Family Issues 27(11): 1487-1511.

Kamo, Y. 2000. "He said, she said": Assessing discrepancies in husbands' and wives' reports on the division of household labor. Social Science Research 29: 459-476.

Kravdal, O. 2001. The high fertility of college educated women in Norway: an artefact of the separate modelling of each parity transition, Demographic Research 5.

Kiernan, K. 2004. Unmarried cohabitation and parenthood in Britain and Europe. Law \& Policy 26(1).

Lundberg, S. and R.A. Pollak. 1996. Bargaining and distribution in marriage. Journal of Economic Perspectives 10(4):139-158.

Lundberg, S. and R.A. Pollak. 2007. The American family and family economics. National Bureau of Economic Research, Working Paper 12908.

Miller, W.B. 1986. Proception: An important fertility behaviour. Demography 23(4): 579-594.

Miller, W.B. and D.J. Pasta. 1994. The psychology of child timing: a measurement instrument and a model. Journal of Applied Social Psychology 24 (3): 218-250.

Miller, W.B., and D.J. Pasta. 1995. Behavioural intentions: which ones predict fertility behaviour in married couples? Journal of Applied Social Psychology 25: 530-555.

Miller, W.B. and D.J. Pasta. 1996. Couple disagreement: Effects on the formation and implementation of fertility decisions. Personal Relationships 3(3): 307-336.

Miller, W.B., Severy, L.J. and D. J. Pasta. 2004. A framework for modeling fertility motivation in couples. Population Studies 58(2): 193-205.

Mitchell, D. and E. Gray. 2007. Declining fertility: Intentions, attitudes and aspirations. Journal of Sociology 43(1): 23-44.

Morgan, S.P. 1985. Individual and couple intentions for more children: a research note. Demography 22(1): $125-132$

Namboodiri, K. 1972. Some observations on the economic framework for fertility analysis. Population Studies 26(2): 185-206.

Perugini, M. and R. P. Bagozzi. 2001. The role of desires and anticipated emotions in goal-directed behaviours: broadening and deepening the theory of planned behavior. British Journal of Social Psychology 40: 79-98.

Prskawetz, A., Sobotka, T., Buber, I., Engelhardt, H. and R. Gisser. 2008. Austria: Persistent low fertility since the mid-1980s. Demographic Research 19(12): 293-356.

Qu, L., Weston, R. and C. Kilmartin. 2000. Children? No children? Effects of changing personal relationship on decisions about having children. Family Matters 57: 14-19.

Rosina, A. and M.R. Testa. 2009. Couples' first child intentions and disagreement: An analysis of the Italian case. European Journal of Population. 25(4): 487.

Rindfuss, R.R., Morgan, P.S. and G. Swicegood. 1988. First births in America: changes in the timing of parenthood. Berkeley and Los Angeles, University of California Press.

Ryder, N.B. 1973. A critique of the National Fertility Study. Demography 10(4): 495-506.

Sobotka, T. 2009. Sub-replacement fertility intentions in Austria. European Journal of Population 25(4): 387-412.

Stewart, S.D. 2002. The effects of stepchildren on childbearing intentions and births. Demography, 39(1): 181-197.

Tazi-Preve, I.M., Bichlbauer, D. and A. Goujon 2004. Gender trouble and its impact on fertility intentions. Yearbook of Population Research in Finland 40: 5-24. 
Testa, M.R. 2006. Childbearing preferences and family issues in Europe, Eurobarometer 2006.

Testa, M.R. and L. Toulemon. 2006. Family Formation in France: Individual Preferences and Subsequent Outcomes. Vienna Yearbook of Population Research: 41-75.

Thomson, E., McDonald, E. and L.L. Bumpass. 1990. Fertility desires and fertility: Hers, his, and theirs. Demography 27(4): 579-588.

Thomson, E. 1997. Couple childbearing desires, intentions, and births. Demography 34(3): 343-354.

Thomson, E. and J.M. Hoem. 1998. Couple childbearing plans and births in Sweden. Demography 35(3): 315-322.

Toulemon, L. 1987. Les souhaits en matière de fécondité: comparaison des résponses des deux conjoints. In: Leridon H. La seconde revolution contraceptive. Travaux et Documents, Cahier No.117, Institut National d'Etudes Démographiques.

Townes, B.D., Beach, L.R., Campbell, F.L. and R.L. Wood. 1980. Family building: A social Psychological study of fertility decisions. Population and Environment 3(3-4): 210-220.

Voas, D. 2003. Conflicting preferences: A reason fertility tends to be too high or too low. Population and Development Review, 29: 627-646.

Williams, R. and E. Thomson. 1985 Can spouses be trusted? A look at husband/wife proxy reports. Demography, 22(1): 115-123. 
Table 1 Distribution of the variables used in the multivariate analysis

\begin{tabular}{|c|c|c|c|c|c|c|c|c|c|c|}
\hline & \multicolumn{3}{|c|}{ First birth } & \multicolumn{3}{|c|}{$\begin{array}{l}\text { Higher birth order } \\
\text { child }\end{array}$} & \multicolumn{2}{|c|}{ First birth } & \multicolumn{2}{|c|}{$\begin{array}{l}\text { Higher birth } \\
\text { order child }\end{array}$} \\
\hline & MF & M & $\mathrm{F}$ & MF & $\mathrm{M}$ & $\mathrm{F}$ & $\begin{array}{c}\text { She } \\
\text { wants }\end{array}$ & $\begin{array}{c}\mathrm{He} \\
\text { wants }\end{array}$ & $\begin{array}{c}\text { She } \\
\text { wants }\end{array}$ & $\begin{array}{c}\mathrm{He} \\
\text { wants }\end{array}$ \\
\hline Partner disagree & 15 & 14 & 16 & 13 & 14 & 13 & 28 & 31 & 29 & 42 \\
\hline $\begin{array}{l}\text { Respondent intends a } \\
\text { child in } 3 \text { years }\end{array}$ & 20 & 19 & 21 & 10 & 11 & 10 & 68 & 60 & 47 & 42 \\
\hline Use of contraception & 78 & 78 & 79 & 74 & 71 & 76 & 38 & 44 & 41 & 47 \\
\hline Married & 18 & 19 & 18 & 79 & 78 & 79 & 37 & 34 & 75 & 77 \\
\hline Cohabiting & 82 & 81 & 82 & 21 & 22 & 21 & 62 & 66 & 25 & 23 \\
\hline $\begin{array}{l}\text { More than } 3 \text { years from } \\
\text { the start of partnership }\end{array}$ & 39 & 36 & 41 & 90 & 88 & 92 & 52 & 49 & 82 & 84 \\
\hline Low educated (she) & 34 & 36 & 33 & 48 & 49 & 48 & 36 & 37 & 45 & 51 \\
\hline Medium educated (she) & 45 & 47 & 44 & 38 & 38 & 38 & 37 & 40 & 40 & 36 \\
\hline High educated (she) & 20 & 17 & 23 & 14 & 13 & 15 & 28 & 23 & 15 & 13 \\
\hline Low educated (he) & 80 & 51 & 49 & 60 & 61 & 60 & 49 & 54 & 53 & 58 \\
\hline Medium educated (he) & 33 & 34 & 32 & 26 & 27 & 25 & 26 & 26 & 29 & 25 \\
\hline High educated (he) & 18 & 15 & 19 & 14 & 12 & 15 & 24 & 21 & 17 & 17 \\
\hline Employed (she) & 75 & 72 & 76 & 62 & 62 & 62 & 90 & 87 & 53 & 51 \\
\hline Not employed (she) & 7 & 7 & 8 & 37 & 37 & 37 & 7 & 6 & 46 & 48 \\
\hline Enrolled in school (she) & 18 & 21 & 16 & 1 & 1 & 1 & 3 & 7 & 1 & 1 \\
\hline Employed (he) & 83 & 81 & 85 & 94 & 94 & 94 & 93 & 91 & 93 & 93 \\
\hline Not employed (he) & 7 & 7 & 6 & 5 & 5 & 5 & 6 & 8 & 6 & 6 \\
\hline Enrolled in school (he) & 10 & 12 & 9 & 1 & 1 & 1 & 1 & 1 & 1 & 1 \\
\hline Age (she) & 28 & 27 & 29 & 36 & 35 & 36 & 30 & 30 & 33 & 33 \\
\hline Age (he) & 31 & 30 & 32 & 38 & 37 & 39 & 34 & 33 & 36 & 36 \\
\hline $\begin{array}{l}\text { Men involved in } \\
\text { household tasks }\end{array}$ & 14 & 24 & 8 & 8 & 13 & 4 & 15 & 19 & 8 & 7 \\
\hline $\begin{array}{l}\text { Men involved in child } \\
\text { care tasks }\end{array}$ & - & - & - & 4 & 8 & 2 & - & - & 4 & 6 \\
\hline Men more educated & 26 & 28 & 25 & 29 & 30 & 28 & 28 & 27 & 30 & 30 \\
\hline Both same education & 37 & 35 & 39 & 40 & 38 & 41 & 36 & 36 & 38 & 42 \\
\hline Women more educated & 37 & 37 & 36 & 31 & 32 & 31 & 36 & 37 & 32 & 28 \\
\hline Men’s stepchildren & 9 & 2 & 13 & 4 & 2 & 6 & 10 & 10 & 2 & 3 \\
\hline Women's stepchildren & 6 & 3 & 8 & 5 & 1 & 7 & 6 & 5 & 7 & 5 \\
\hline $\begin{array}{l}\text { More than } 3 \text { years from } \\
\text { the birth of last child }\end{array}$ & - & - & - & 63 & 61 & 64 & - & - & 42 & 43 \\
\hline One common child & - & - & - & 35 & 37 & 35 & - & - & 61 & 61 \\
\hline Two common children & - & - & - & 46 & 44 & 47 & - & - & 31 & 29 \\
\hline $\begin{array}{l}\text { Three or more common } \\
\text { children }\end{array}$ & - & - & - & 18 & 18 & 18 & - & - & 8 & 10 \\
\hline N. cases & 1412 & 585 & 827 & 1990 & 738 & 1252 & 262 & 274 & 245 & 296 \\
\hline
\end{tabular}


Table 2 Childbearing desires and its correlates. Values in per cent. Weighted data

\begin{tabular}{l|cc|cc|cc}
\hline \multirow{2}{*}{$\begin{array}{l}\text { Couple's current fertility } \\
\text { desires }\end{array}$} & \multicolumn{2}{|c|}{ Distribution } & \multicolumn{2}{c|}{ Contraceptive use \% } & \multicolumn{2}{c}{ Fertility intentions \% } \\
\cline { 2 - 7 } & Childless & Parent & Childless & Parent & Female & Male \\
\hline Both want a child & 12 & 9 & 27 & 33 & 67 & 68 \\
She wants, he does not & 5 & 4 & 67 & 68 & 35 & 22 \\
He wants, she does not & 6 & 6 & 85 & 68 & 13 & 26 \\
Both do not want a child & 77 & 81 & 88 & 78 & 6 & 4 \\
\hline
\end{tabular}

Note. The proportion of fertility intentions refer to the respondents reporting that they are very sure to intend to have a child during the next three years 


\section{Figure 1}

Couple's current fertility desires by number of shared children.

Values in per cent. Weighted data.

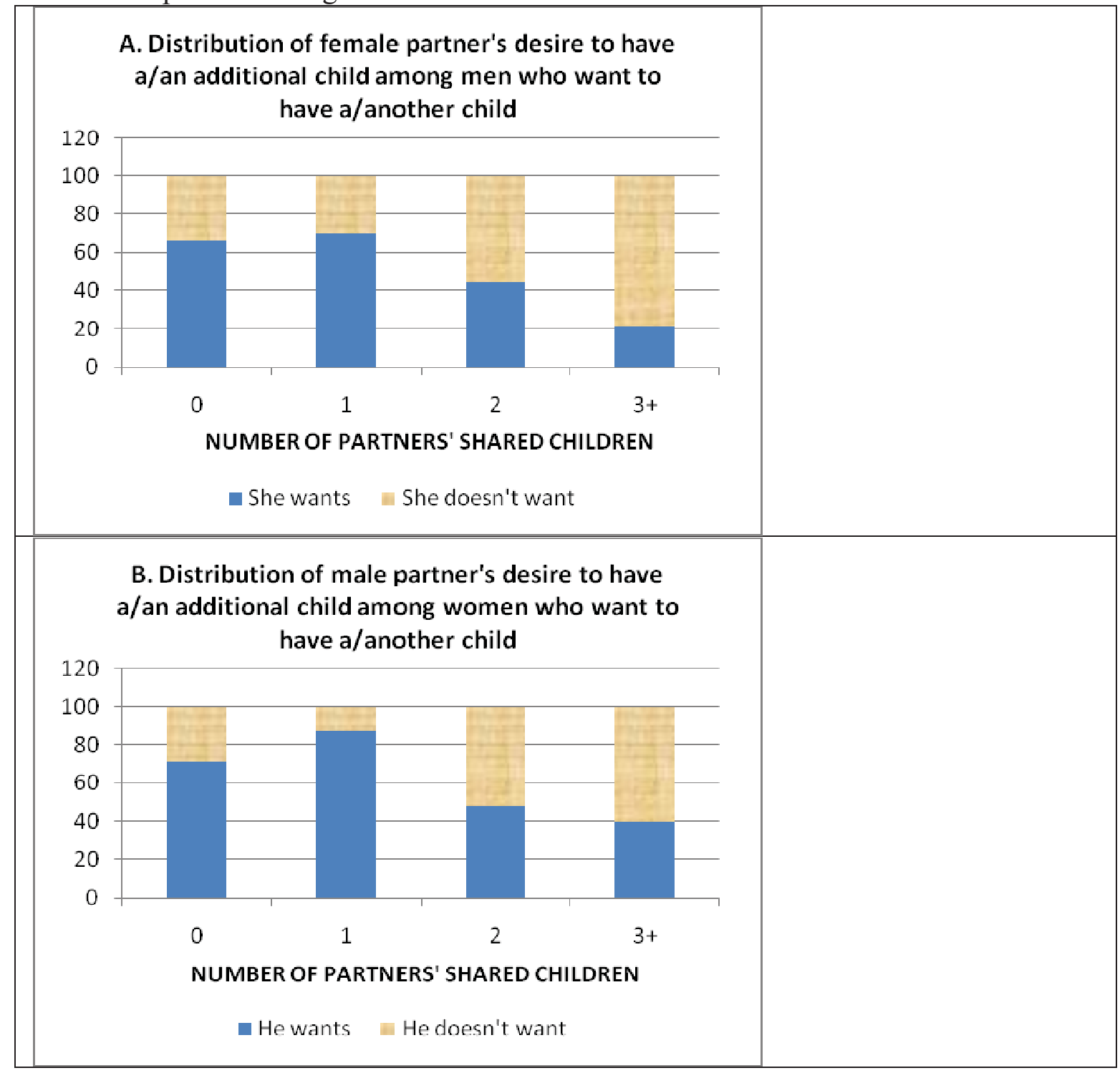




\section{Figure 2}

Couple's current fertility desires by female partner's age.

Values in per cent. Weighted data.

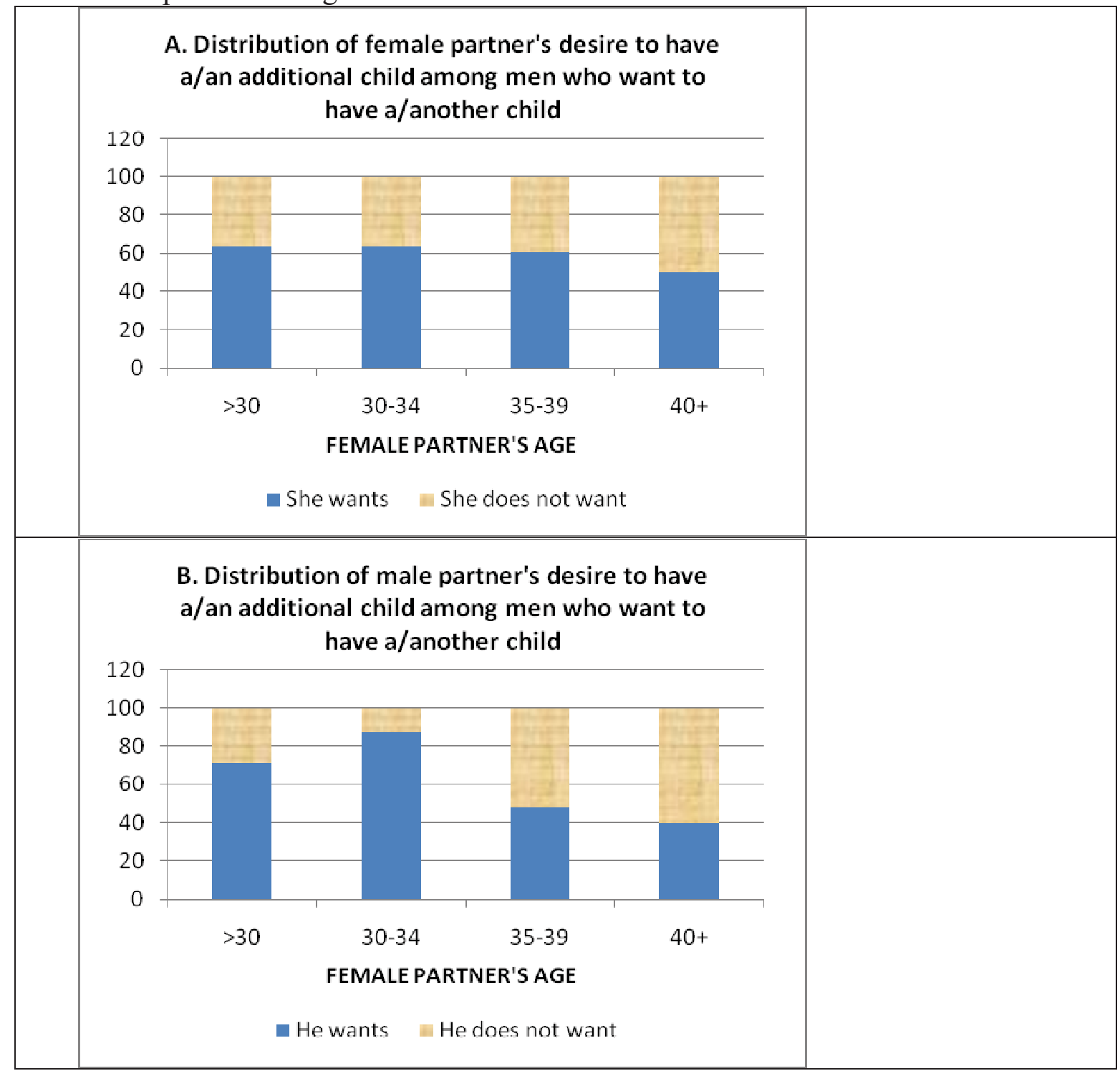


Table 3 Estimates of logistic models on current couple's childbearing desires.

\begin{tabular}{|c|c|c|c|c|c|c|}
\hline & \multicolumn{2}{|c|}{$\begin{array}{c}\text { Model I: } \\
\text { Couple's } \\
\text { disagreement versus } \\
\text { agreement }\end{array}$} & \multicolumn{2}{|c|}{$\begin{array}{c}\text { Model II: } \\
\text { Male negative } \\
\text { disagreement }\end{array}$} & \multicolumn{2}{|c|}{$\begin{array}{c}\text { Model III: } \\
\text { Female negative } \\
\text { disagreement }\end{array}$} \\
\hline & $\begin{array}{l}\text { First } \\
\text { birth }\end{array}$ & $\begin{array}{l}\text { Higher } \\
\text { birth }\end{array}$ & $\begin{array}{l}\text { First } \\
\text { birth }\end{array}$ & $\begin{array}{l}\text { Higher } \\
\text { birth }\end{array}$ & $\begin{array}{l}\text { First } \\
\text { birth }\end{array}$ & $\begin{array}{l}\text { Higher } \\
\text { birth }\end{array}$ \\
\hline $\begin{array}{l}\text { Fertility desire } \\
\text { One of the partners wants a child }\end{array}$ & 3.0 & 3.7 & & & & \\
\hline $\begin{array}{l}\text { Type of union (ref. Married) } \\
\text { Cohabiting }\end{array}$ & 1.4 & 0.2 & 1.4 & 1.1 & 2.2 & 0.08 \\
\hline $\begin{array}{l}\text { Duration of union }(\text { ref. }<=3 \text { ) } \\
\text { More than } 3 \text { years }\end{array}$ & -0.2 & 0.02 & 0.03 & 0.3 & -0.05 & 0.3 \\
\hline $\begin{array}{l}\text { Woman's education (ref. Medium) } \\
\text { Low } \\
\text { High }\end{array}$ & $\begin{array}{l}-0.2 \\
-0.2\end{array}$ & $\begin{array}{r}-\mathbf{0 . 9} \\
0.6\end{array}$ & $\begin{array}{r}-0.1 \\
0.4\end{array}$ & $\begin{array}{r}-1.7 \\
1.1\end{array}$ & $\begin{array}{l}-0.9 \\
-0.2\end{array}$ & $\begin{array}{r}-0.5 \\
0.7\end{array}$ \\
\hline $\begin{array}{l}\text { Man's education (ref. Medium) } \\
\text { Low } \\
\text { High }\end{array}$ & $\begin{array}{l}0.1 \\
0.5\end{array}$ & $\begin{array}{c}\mathbf{0 . 6} \\
-0.7\end{array}$ & $\begin{array}{l}0.2 \\
0.2 \\
\end{array}$ & $\begin{array}{r}1.0 \\
-1.5\end{array}$ & $\begin{array}{l}0.6 \\
0.3\end{array}$ & $\begin{array}{c}1.1 \\
-0.5\end{array}$ \\
\hline $\begin{array}{l}\text { Woman's employment (ref. Empl.) } \\
\text { Not employed } \\
\text { Enrolled in school }\end{array}$ & $\begin{array}{l}-\mathbf{0 . 6} \\
-0.2\end{array}$ & $\begin{array}{c}-0.002 \\
- \\
\end{array}$ & $\begin{array}{l}-0.4 \\
-0.2\end{array}$ & $\begin{array}{c}0.3 \\
-\end{array}$ & $\begin{array}{l}0.5 \\
0.4\end{array}$ & $\begin{array}{c}0.3 \\
-\end{array}$ \\
\hline $\begin{array}{l}\text { Man's employment (ref. Empl.) } \\
\text { Not employed } \\
\text { Enrolled in school }\end{array}$ & $\begin{array}{r}0.8 \\
-1.2 \\
\end{array}$ & $\begin{array}{c}0.06 \\
- \\
\end{array}$ & $\begin{array}{c}1.0 \\
0.03\end{array}$ & $\begin{array}{c}-0.1 \\
- \\
\end{array}$ & $\begin{array}{l}1.3 \\
2.2 \\
\end{array}$ & $\begin{array}{c}-0.5 \\
-\end{array}$ \\
\hline $\begin{array}{l}\text { Woman's age } \\
(\text { Age-33) } \\
(\text { Age-33)^2 }\end{array}$ & $\begin{array}{c}0.04 \\
0.002 \\
\end{array}$ & $\begin{array}{c}0.008 \\
-0.004 \\
\end{array}$ & $\begin{array}{c}0.06 \\
0.0003\end{array}$ & $\begin{array}{c}0.09 \\
\mathbf{- 0 . 0 1}\end{array}$ & $\begin{array}{c}0.05 \\
0.009 \\
\end{array}$ & $\begin{array}{c}0.06 \\
-0.0003\end{array}$ \\
\hline $\begin{array}{l}\text { Gender division of household tasks } \\
\text { (ref. Man not involved) } \\
\text { Man participates } \\
\text { Gender division of childcare tasks } \\
\text { (ref. Man not involved) } \\
\text { Man participates }\end{array}$ & 0.03 & -0.5 & -0.5 & -2.2 & 0.5 & 1.3 \\
\hline $\begin{array}{l}\text { Education diff. (Ref. No diff.) } \\
\text { Man more educated } \\
\text { Woman more educated }\end{array}$ & $\begin{array}{l}-0.5 \\
0.05\end{array}$ & $\begin{array}{c}0.6 \\
-0.7\end{array}$ & $\begin{array}{l}-0.6 \\
-0.2 \\
\end{array}$ & $\begin{array}{r}1.2 \\
-1.1\end{array}$ & $\begin{array}{l}-1.0 \\
-0.6\end{array}$ & $\begin{array}{c}0.7 \\
-0.6\end{array}$ \\
\hline $\begin{array}{l}\text { Stepchildren (No stepchild) } \\
\text { Man's stepchildren } \\
\text { Woman's stepchildren }\end{array}$ & $\begin{array}{c}-0.1 \\
0.2 \\
\end{array}$ & $\begin{array}{l}\mathbf{1 . 2} \\
0.1\end{array}$ & $\begin{array}{c}-0.01 \\
0.3 \\
\end{array}$ & $\begin{array}{l}2.6 \\
0.6 \\
\end{array}$ & $\begin{array}{c}0.01 \\
0.4 \\
\end{array}$ & $\begin{array}{c}3.1 \\
-0.3 \\
\end{array}$ \\
\hline $\begin{array}{l}\text { Shared children (Ref. One) } \\
\text { Two children } \\
\text { Three or more children }\end{array}$ & - & $\begin{array}{l}1.0 \\
1.3\end{array}$ & - & $\begin{array}{l}2.4 \\
2.4\end{array}$ & - & $\begin{array}{l}1.1 \\
2.1\end{array}$ \\
\hline $\begin{array}{l}\text { Time from last birth (Ref. }<=3 \text { years) } \\
\text { More than three years }\end{array}$ & - & 0.3 & - & 0.4 & - & 0.04 \\
\hline Intercept & -3.8 & -3.6 & -1.8 & -2.2 & -2.4 & -1.4 \\
\hline N. cases & 1412 & 1990 & 262 & 245 & 274 & 296 \\
\hline
\end{tabular}

Coefficients statistically significant are marked in bold.

Models controlled for men's age and respondent's geographical area of residence. 
Table 4 Estimates of logistic models on individual intentions to have a child in 3 years.

\begin{tabular}{|c|c|c|c|c|c|c|}
\hline & \multicolumn{2}{|c|}{ ALL } & \multicolumn{2}{|c|}{ MALES } & \multicolumn{2}{|c|}{ FEMALES } \\
\hline & $\begin{array}{l}\text { First } \\
\text { birth }\end{array}$ & $\begin{array}{l}\text { Higher } \\
\text { birth }\end{array}$ & First birth & $\begin{array}{l}\text { Higher } \\
\text { birth }\end{array}$ & $\begin{array}{l}\text { First } \\
\text { birth }\end{array}$ & $\begin{array}{l}\text { Higher } \\
\text { birth }\end{array}$ \\
\hline $\begin{array}{l}\text { Couple's child desires } \\
\text { Respondent wants a child }\end{array}$ & 2.3 & 2.1 & 2.2 & 2.3 & 2.8 & 2.2 \\
\hline Partner wants a child & 1.3 & 1.2 & 2.0 & 1.6 & 0.8 & 1.2 \\
\hline $\begin{array}{l}\text { Type of union (ref. Married) } \\
\text { Cohabiting }\end{array}$ & -0.7 & 0.4 & -1.0 & 0.6 & -0.5 & 0.04 \\
\hline $\begin{array}{l}\text { Duration of union }(\text { ref. }<=3 \text { ) } \\
\text { More than three years }\end{array}$ & -0.01 & -0.03 & 0.4 & 0.2 & -0.3 & -0.7 \\
\hline $\begin{array}{l}\text { Woman's education ( ref. Medium) } \\
\text { Low } \\
\text { High }\end{array}$ & $\begin{array}{l}0.1 \\
-0.5\end{array}$ & $\begin{array}{c}0.4 \\
-0.1\end{array}$ & $\begin{array}{c}-0.6 \\
0.4\end{array}$ & $\begin{array}{l}0.8 \\
-0.4\end{array}$ & $\begin{array}{c}0.4 \\
\mathbf{- 1 . 0}\end{array}$ & $\begin{array}{l}0.3 \\
0.1\end{array}$ \\
\hline $\begin{array}{l}\text { Man's education (ref. Medium) } \\
\text { Low } \\
\text { High }\end{array}$ & $\begin{array}{c}-0.3 \\
0.5\end{array}$ & $\begin{array}{c}-0.2 \\
0.9\end{array}$ & $\begin{array}{c}0.3 \\
0.05\end{array}$ & $\begin{array}{r}-1.2 \\
0.6\end{array}$ & $\begin{array}{c}-0.4 \\
0.7\end{array}$ & $\begin{array}{l}1.0 \\
1.7\end{array}$ \\
\hline $\begin{array}{l}\text { Woman's employment (ref. Empl.) } \\
\text { Not employed } \\
\text { Enrolled in school }\end{array}$ & $\begin{array}{l}-0.5 \\
-0.4\end{array}$ & $\begin{array}{l}0.07 \\
-1.1\end{array}$ & $\begin{array}{r}-0.3 \\
0.2\end{array}$ & $\begin{array}{l}0.7 \\
-1.1\end{array}$ & $\begin{array}{l}-0.3 \\
-0.9\end{array}$ & $\begin{array}{l}-\mathbf{0 . 7} \\
-0.5\end{array}$ \\
\hline $\begin{array}{l}\text { Man's employment (ref. Empl.) } \\
\text { Not employed } \\
\text { Enrolled in school }\end{array}$ & $\begin{array}{l}-0.2 \\
-0.6\end{array}$ & $\begin{array}{l}0.08 \\
-0.8\end{array}$ & $\begin{array}{l}-2.3 \\
-1.5\end{array}$ & $\begin{array}{l}0.3 \\
-0.8\end{array}$ & $\begin{array}{c}0.7 \\
-0.2\end{array}$ & $\begin{array}{l}-0.8 \\
-1.7\end{array}$ \\
\hline $\begin{array}{l}\text { Woman's age } \\
(\text { Age-33) } \\
(\text { Age-33)^2 }\end{array}$ & $\begin{array}{l}-0.1 \\
-0.01\end{array}$ & $\begin{array}{l}-0.08 \\
0.001\end{array}$ & $\begin{array}{l}-0.07 \\
-0.01\end{array}$ & $\begin{array}{r}-0.005 \\
0.004\end{array}$ & $\begin{array}{c}-0.1 \\
-0.01\end{array}$ & $\begin{array}{c}-0.1 \\
0.002\end{array}$ \\
\hline $\begin{array}{l}\text { Gender division of household tasks } \\
\text { (ref. Man not involved) } \\
\text { Man participates } \\
\text { Gender division of childcare tasks } \\
\text { (ref. Man not involved) } \\
\text { Man participates }\end{array}$ & -0.4 & -0.3 & -0.03 & $\begin{array}{l}-0.01 \\
-0.2\end{array}$ & -0.4 & $\begin{array}{l}-0.9 \\
-1.1\end{array}$ \\
\hline $\begin{array}{l}\text { Educational diff. (Ref. None) } \\
\text { Man more educated } \\
\text { Woman more educated }\end{array}$ & $\begin{array}{c}-0.3 \\
0.4\end{array}$ & $\begin{array}{c}\mathbf{- 1 . 0} \\
0.3\end{array}$ & $\begin{array}{c}0.2 \\
-0.01\end{array}$ & $\begin{array}{c}\mathbf{- 1 . 5} \\
0.8\end{array}$ & $\begin{array}{c}-0.6 \\
0.4\end{array}$ & $\begin{array}{l}-0.4 \\
-0.2\end{array}$ \\
\hline $\begin{array}{l}\text { Stepchildren (Ref. No step } \\
\text { children) } \\
\text { Man's stepchildren } \\
\text { Woman's stepchildren }\end{array}$ & $\begin{array}{c}-\mathbf{0 . 9} \\
0.006\end{array}$ & $\begin{array}{c}0.2 \\
-0.3\end{array}$ & $\begin{array}{c}1.0 \\
-0.4\end{array}$ & $\begin{array}{c}- \\
1.4\end{array}$ & $\begin{array}{c}\mathbf{- 1 . 5} \\
0.2\end{array}$ & $\begin{array}{l}0.09 \\
-0.8\end{array}$ \\
\hline $\begin{array}{l}\text { Shared children (Ref. One) } \\
\text { Two children } \\
\text { Three or more children }\end{array}$ & - & $\begin{array}{r}-1.3 \\
-1.3\end{array}$ & - & $\begin{array}{r}-1.4 \\
-1.0\end{array}$ & - & $\begin{array}{r}-1.4 \\
-1.5\end{array}$ \\
\hline $\begin{array}{l}\text { Time elapsed from last birth (Ref. } \\
<=3 \text { years) } \\
\text { More than three years }\end{array}$ & - & -0.9 & - & -1.2 & - & -0.7 \\
\hline Intercept & -1.1 & -2.2 & -1.6 & -2.2 & -0.9 & -2.4 \\
\hline N. cases & 1412 & 1990 & 585 & 738 & 827 & 1246 \\
\hline
\end{tabular}

Coefficients statistically significant are marked in bold.

Models controlled for men's age and respondent's geographical area of residence. 
Table 5 Estimates of logistic models on couple's proceptive behaviour.

\begin{tabular}{|c|c|c|c|c|c|c|}
\hline & \multicolumn{2}{|c|}{ ALL } & \multicolumn{2}{|c|}{ MALES } & \multicolumn{2}{|c|}{ FEMALES } \\
\hline & $\begin{array}{l}\text { First } \\
\text { birth }\end{array}$ & $\begin{array}{l}\text { Higher } \\
\text { birth }\end{array}$ & $\begin{array}{l}\text { First } \\
\text { birth }\end{array}$ & $\begin{array}{l}\text { Higher } \\
\text { birth }\end{array}$ & First birth & $\begin{array}{l}\text { Higher } \\
\text { birth }\end{array}$ \\
\hline $\begin{array}{l}\text { Couple's child desires } \\
\text { Respondent wants a child } \\
\text { Partner wants a child }\end{array}$ & $\begin{array}{l}0.7 \\
0.6\end{array}$ & $\begin{array}{l}1.1 \\
0.7\end{array}$ & $\begin{array}{l}0.6 \\
0.9\end{array}$ & $\begin{array}{l}0.8 \\
0.6\end{array}$ & $\begin{array}{l}1.0 \\
0.5\end{array}$ & $\begin{array}{l}1.4 \\
0.7\end{array}$ \\
\hline $\begin{array}{l}\text { Respondents' intentions } \\
\text { Very sure to intend a child }\end{array}$ & 0.5 & 0.4 & 0.2 & 0.6 & 0.7 & 0.5 \\
\hline $\begin{array}{l}\text { Type of union (ref. Married) } \\
\text { Cohabiting }\end{array}$ & -0.4 & -0.5 & -0.6 & -0.7 & -0.2 & -0.4 \\
\hline $\begin{array}{l}\text { Duration of union }(\text { ref. }<=3 \text { ) } \\
\text { More than three years }\end{array}$ & 0.3 & -0.1 & 0.3 & -0.4 & 0.3 & 0.2 \\
\hline $\begin{array}{l}\text { Woman's education ( ref. Medium) } \\
\text { Low } \\
\text { High }\end{array}$ & $\begin{array}{c}0.1 \\
-0.01\end{array}$ & $\begin{array}{c}0.3 \\
0.08\end{array}$ & $\begin{array}{l}0.2 \\
0.3\end{array}$ & $\begin{array}{l}0.2 \\
0.2\end{array}$ & $\begin{array}{l}-0.03 \\
-0.2\end{array}$ & $\begin{array}{c}0.2 \\
-0.04\end{array}$ \\
\hline $\begin{array}{l}\text { Man's education (ref. Medium) } \\
\text { Low } \\
\text { High }\end{array}$ & $\begin{array}{l}-0.08 \\
-\mathbf{0 . 4}\end{array}$ & $\begin{array}{r}0.3 \\
-0.1\end{array}$ & $\begin{array}{l}-0.2 \\
-\mathbf{- 0 . 6}\end{array}$ & $\begin{array}{c}0.5 \\
-0.3\end{array}$ & $\begin{array}{c}0.1 \\
-0.4\end{array}$ & $\begin{array}{c}0.1 \\
0.009\end{array}$ \\
\hline $\begin{array}{l}\text { Woman's employment (ref. Empl.) } \\
\text { Not employed } \\
\text { Enrolled in school }\end{array}$ & $\begin{array}{r}\mathbf{0 . 7} \\
-0.3\end{array}$ & $\begin{array}{l}0.3 \\
0.3\end{array}$ & $\begin{array}{c}\mathbf{0 . 6} \\
-0.2\end{array}$ & $\begin{array}{c}0.09 \\
0.2\end{array}$ & $\begin{array}{r}\mathbf{0 . 8} \\
-0.3\end{array}$ & $\begin{array}{l}0.5 \\
1.5\end{array}$ \\
\hline $\begin{array}{l}\text { Man's employment (ref. Empl.) } \\
\text { Not employed } \\
\text { Enrolled in school }\end{array}$ & $\begin{array}{c}0.2 \\
-\mathbf{0 . 9}\end{array}$ & $\begin{array}{c}0.4 \\
-0.7\end{array}$ & $\begin{array}{r}-0.1 \\
-1.6\end{array}$ & $\begin{array}{l}-0.07 \\
-0.2\end{array}$ & $\begin{array}{c}\mathbf{0 . 5} \\
-0.4\end{array}$ & $\begin{array}{c}0.9 \\
-\end{array}$ \\
\hline $\begin{array}{l}\text { Woman's age } \\
(\text { Age- } 33) \\
(\text { Age- } 33)^{\wedge} 2\end{array}$ & $\begin{array}{c}0.05 \\
0.002\end{array}$ & $\begin{array}{l}0.03 \\
0.00\end{array}$ & $\begin{array}{c}0.03 \\
0.001\end{array}$ & $\begin{array}{c}0.05 \\
-0.003\end{array}$ & $\begin{array}{c}0.07 \\
0.004\end{array}$ & $\begin{array}{c}0.01 \\
0.002\end{array}$ \\
\hline $\begin{array}{l}\text { Gender division of household tasks } \\
\text { (ref. Man not involved) } \\
\text { Man participates } \\
\text { Gender division of child care tasks } \\
\text { (ref. Man not involved) } \\
\text { Man participates }\end{array}$ & 0.2 & 0.3 & 0.2 & 0.4 & 0.001 & -1.3 \\
\hline $\begin{array}{l}\text { Educational diff. (Ref. None) } \\
\text { Man more educated } \\
\text { Woman more educated }\end{array}$ & $\begin{array}{r}-0.07 \\
0.06\end{array}$ & $\begin{array}{c}-0.004 \\
0.3\end{array}$ & $\begin{array}{c}-0.1 \\
0.2\end{array}$ & $\begin{array}{c}-0.1 \\
0.2\end{array}$ & $\begin{array}{l}0.03 \\
-0.1\end{array}$ & $\begin{array}{l}0.1 \\
0.2\end{array}$ \\
\hline $\begin{array}{l}\text { Stepchildren (Ref. none) } \\
\text { Man's stepchildren } \\
\text { Woman's stepchildren }\end{array}$ & $\begin{array}{c}-\mathbf{0 . 5} \\
-0.01\end{array}$ & $\begin{array}{c}0.4 \\
-0.3\end{array}$ & $\begin{array}{l}-0.6 \\
-0.2\end{array}$ & $\begin{array}{c}1.8 \\
-0.8\end{array}$ & $\begin{array}{c}\mathbf{- 0 . 7} \\
0.2\end{array}$ & $\begin{array}{l}-0.2 \\
-0.2\end{array}$ \\
\hline $\begin{array}{l}\text { Shared children (Ref. One) } \\
\text { Two children } \\
\text { Three or more children }\end{array}$ & - & $\begin{array}{c}-0.1 \\
0.2\end{array}$ & - & $\begin{array}{c}-0.01 \\
0.3\end{array}$ & - & $\begin{array}{c}-0.3 \\
0.006\end{array}$ \\
\hline $\begin{array}{l}\text { Time elapsed from last birth (Ref. } \\
<=3 \text { years) } \\
\text { More than three years }\end{array}$ & - & -0.04 & - & 0.1 & - & 0.02 \\
\hline Intercept & -0.7 & -1.7 & -0.4 & -1.6 & -1.2 & -2.1 \\
\hline N. cases & 1412 & 1990 & 585 & 738 & 827 & 1246 \\
\hline
\end{tabular}

Coefficients statistically significant are marked in bold.

Models controlled for men's age and respondent's geographical area of residence. 


\section{Figure 3}

Accuracy level of respondent's proxy report of partner's fertility desire in the sub-sample of those respondents with an interviewed partner. Weighted data.

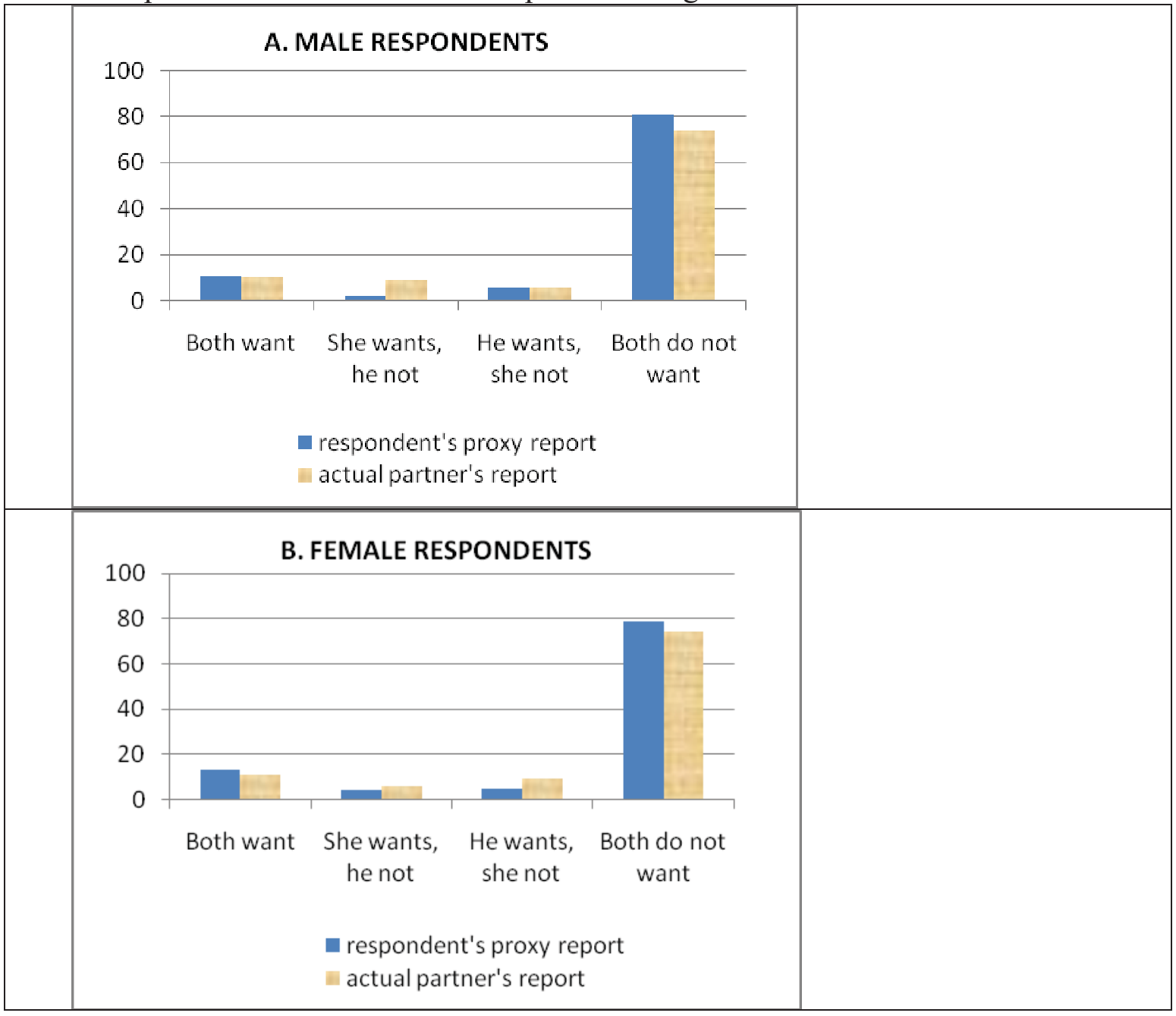




\section{APPENDIX 1}

Table A1 Survey questions used in the analysis:

\begin{tabular}{|l|l|}
\hline English & German \\
\hline $\begin{array}{l}\text { Do you/yourself want to have a/another } \\
\text { child now? }\end{array}$ & $\begin{array}{l}\text { Möchten Sie selbst jetzt ein (weiteres) } \\
\text { Kind? }\end{array}$ \\
\hline $\begin{array}{l}\text { Couples do not always have the same } \\
\text { feelings about the number or timing of } \\
\text { children. Does your partner want to have } \\
\text { a/another child now? }\end{array}$ & $\begin{array}{l}\text { Paare sind sich nicht immer darüber, wann } \\
\text { und wie viele Kinder sie haben möchten. } \\
\text { Möchten Ihre Partnerin/Ihr Partner jetzt ein } \\
\text { Kind? }\end{array}$ \\
\hline $\begin{array}{l}\text { Do you intend to have a/another child } \\
\text { during the next three years? }\end{array}$ & $\begin{array}{l}\text { Ich habe Sie zuvor gefragt, ob Sie derzeit } \\
\text { ein Kind möchten. Ich möchte Sie nun zu } \\
\text { Ihrem Kinderwunsch in den nächsten 3 } \\
\text { Jahren fragen. Haben Sie vor, in den } \\
\text { nächsten drei Jahren ein Kind zu } \\
\text { bekommen? }\end{array}$ \\
\hline Do you currently use contraception & Verhüten Sie derzeit? \\
\hline
\end{tabular}

Note.

(1) The English version corresponds almost perfectly to the English wording adopted for the GGS core international questionnaire. The only exception is the item on contraception that in the core questionnaire is asked as follows: 'Are you or your partner/spouse using or doing any of the things listed on this card to prevent pregnancy at this time?' Please name all of the things you use or do. Show Card 609: Contraception [Comment: Country-specific list that should cover the range of available methods with commonly understandable labels in a country] 


\section{VIENNA INSTITUTE OF DEMOGRAPHY}

\section{Working Papers}

Buber, Isabella, Wissenschaftlerinnen in Österreich - Zusatzerhebung im Rahmen des GGS.Dokumentation der Datenerhebung und deskriptive Ergebnisse, VID Working Paper 02/2010.

Kuhn, Michael, Stefan Wrzaczek, Alexia Prskawetz, and Gustav Feichtinger, Externalities in a Life-Cycle Model with Endogenous Survival, VID Working Paper $01 / 2010$.

Prettner, Klaus, Population Ageing and Endogenous Economic Growth, VID Working Paper 08/2009.

Št’astná, Anna and Tomáš Sobotka, Changing Parental Leave and Shifts in Second and Third-Birth Rates in Austria, VID Working Paper 07/2009.

Prettner, Klaus and Alexia Prskawetz, Decreasing Fertility, Economic Growth and the Intergenerational Wage Gap, VID Working Paper 06/2009.

Wegner, Christian and Marc Luy, Determinants of General Health and Specific Diseases of Elderly Women and Men: A Longitudinal Analysis for Western and Eastern Germany, VID Working Paper 05/2009.

Wrzaczek, Stefan, Michael Kuhn, Alexia Prskawetz, and Gustav Feichtinger, The Reproductive Value in Distributed Optimal Control Models, VID Working Paper 04/2009.

Wendland, Maike und Isabella Buber, Ein Vergleich der Ergebnisse der ersten Welle des Österreichischen,, Survey of Health, Ageing and Retirement in Europe " (SHARE) und der „Österreichischen Gesundheitsbefragung“ (ATHIS), VID Working Paper 03/2009.

Thomson, Elizabeth, Maria Winkler-Dworak, Martin Spielauer, and Alexia Prskawetz, Union Instability as an Engine of Fertility, VID Working Paper 02/2009.

Grafeneder-Weissteiner, Theresa and Klaus Prettner, Agglomeration and population ageing in a two region model of exogenous growth, VID Working Paper 01/2009.

Skirbekk, Vegard, Anne Goujon, and Eric Kaufmann, Secularism or Catholicism? The Religious Composition of the United States to 2043, VID Working Paper 04/2008.

The Vienna Institute of Demography Working Paper Series receives only limited review. Views or opinions expressed herein are entirely those of the authors. 